\title{
The Current Situation and Suggestions of "Mathematics Drawing Book" in the Teaching of Lower Grades of Primary School
}

\author{
Yali Hong \\ Affiliated Primary School of Southwest University in Beibei District, Chongqing, China \\ Email: 26236797@qq.com
}

How to cite this paper: Hong, Y. L. (2021). The Current Situation and Suggestions of "Mathematics Drawing Book" in the Teaching of Lower Grades of Primary School. Creative Education, 12, 2025-2037. https://doi.org/10.4236/ce.2021.129155

Received: August 6, 2021

Accepted: September 5, 2021

Published: September 8, 2021

Copyright $\odot 2021$ by author(s) and Scientific Research Publishing Inc. This work is licensed under the Creative Commons Attribution International License (CC BY 4.0).

http://creativecommons.org/licenses/by/4.0/

\section{(c) (i) Open Access}

\begin{abstract}
Objective: The purpose of this study was to sort out the application of "mathematical picture books" in primary school mathematics teaching, and make recommendations according to the status quo. Materials and Methods: Using the visual analysis method of knowledge map, this study combed through the relevant literature of "mathematical drawing book" from 2008 to 2021. Results: The study found that the number of documents related to "mathematical drawing book" has been increasing year by year since 2012. Wu Nianyang, Zhang Xia and other scholars and their cutting-edge literature are quite influential; "Mathematics Drawing Book" in "Primary School Teaching", "Early Childhood Teaching" and other aspects of the research contained more, while the most concentrated is in the "low-level teaching in primary school" application, whose research content mainly revolves around three major issues elaborated, namely "why the use of 'mathematics drawing book' teaching", "what do you teach with "mathematical drawing"” and how to teach with "mathematics drawing book"? Conclusion: The organization recommends the lower-section-of-primary-school related mathematics drawing book, but also put forward three suggestions for the use of mathematics drawing book: from mathematics drawing this lesson to mathematics drawing this curriculum, from school teaching to family education, from teachers' teaching to students' independent reading, that is, from passive learning to active learning.
\end{abstract}

\section{Keywords}

Math Drawing, Teaching, Application Status, Suggestions

\section{Introduction}

"Mathematics drawing book" is a topic of general concern in mathematics teach- 
ing in primary schools at present, especially in the lower grades. To say "mathematical drawing book" first starts from the "drawing book". Drawing book, called "picture book" in Britain, as the name implies, counts for "painting book", and is also called drawing book to map-based, with concise and vivid language and exquisite and beautiful painting closely colluded with the composition of children's literature works. Wherein, each picture has a rich connotation, and between the picture and the map presents a unique narrative relationship, expressing the overall mood of the drawing book which consequently contains a wealth of knowledge, emotion and philosophy of life. A drawing book has bright colors, distinctive themes, a simple plot, imaginary space, interesting stories, profound connotations and so on. A good drawing book is not only telling a story, but also helps to enhance students' observation, enrich their imagination, and sublimate their spiritual realm (Matsui, 2017).

The prototype of the drawing can be traced back to the 17th century book "Illustration of the World", in which the author Kwa menius tries to help children read and learn better through illustrations; In the 19th century, Europe produced a real picture book, and the development of the drawing book began to develop, by the 1930s, the painting book began to flourish in the United States, the1950s and 1960s began to prevail in Japan, Taiwan was influenced by Japan, in the 1960s began to introduce the drawing book, to the 1980s, Taiwan painting book development into a better environment. In mainland China, around 2000, various publishing houses began to pay attention to the drawing book, thus "painting book" in our country began. Since then, children's literature, art aesthetics, education have begun to study the picture book. "Mathematics drawing book" refers to the storyline contains mathematical concepts or designed for mathematical concepts or mainly with vivid graphics to present interesting mathematical stories, so that students in vivid images of the story to understand the concept of mathematics, master mathematical thinking methods, improve mathematical literacy.

\section{A Review of the Relevant Research on "Mathematical Drawings"}

\subsection{CNKI Visual Analysis Results}

In CNKI, the author searched the literature on the theme of "Mathematical Drawing, and retrieved 888 papers on related topics. The annual trends of the publication of the relevant "Mathematical Drawing Book" by CNKI visual analysis are as follows:

As shown in Figure 1, since 2008, the number of articles published about "Mathematical Drawings" has been increasing year by year. The number of publications will continue to rise in 2019 and 2020, indicating that research on "mathematical drawings" has entered a booming phase in recent years. There were 19 papers in the literature reviewed, accounting for $2.1 \%$. Journal papers accounted for $89.9 \%$, i.e. 798 articles, and other articles accounted for $8 \%$.

As shown in Figure 2, the subject distribution is mainly in primary education, 


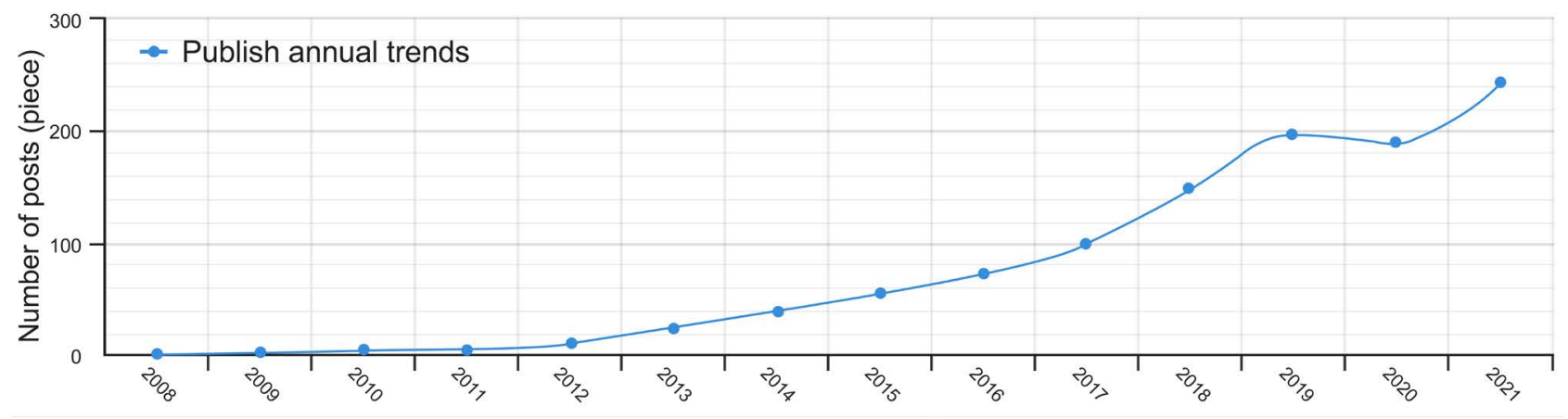

Figure 1. Years and respective quantity of literature published.

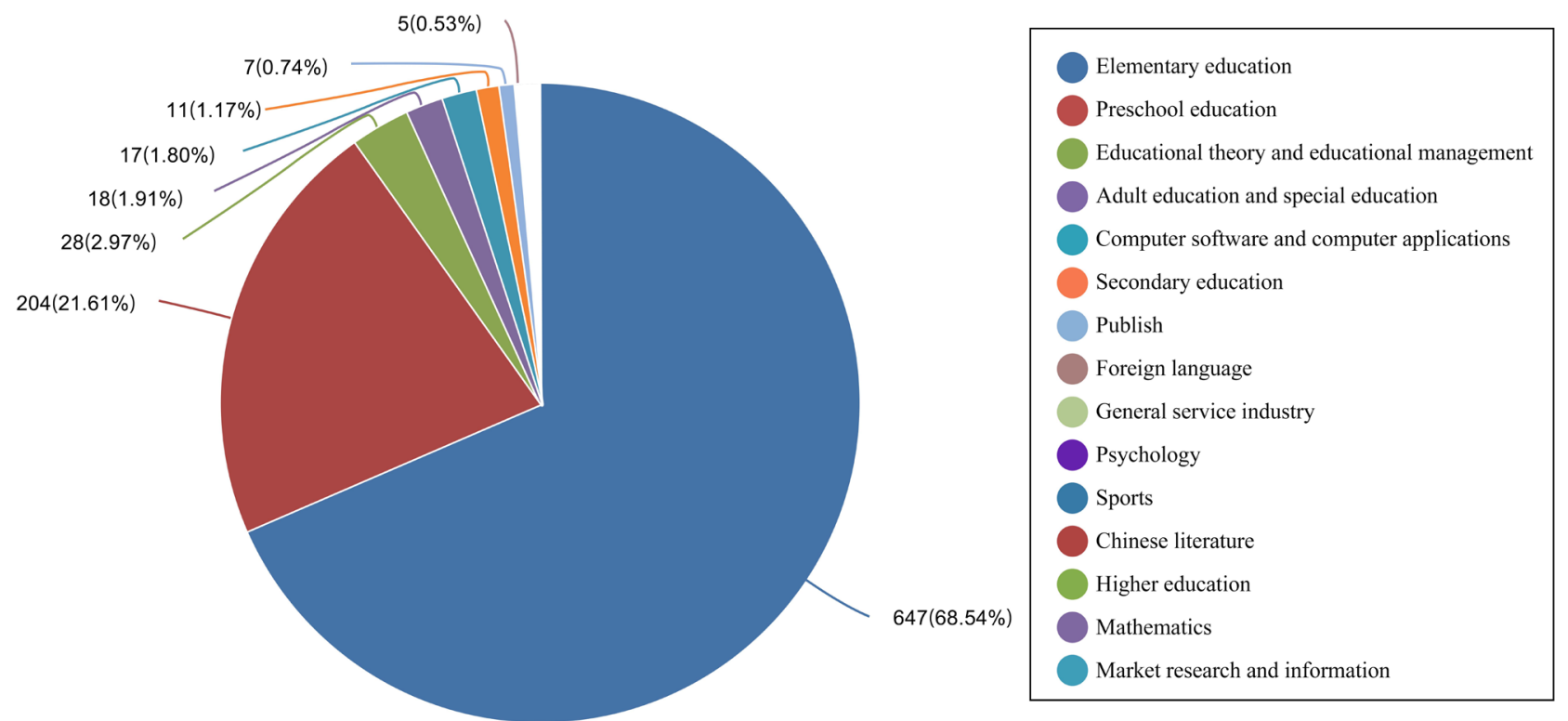

Figure 2. The distribution of disciplines.

a total of 647, accounting for 68.54\%, plus a total of 204 preschool education, accounting for $21.61 \%$. It can be seen that the relevant "mathematical picture books" literature is widely used in primary education, followed by preschool education.

\subsection{Cite Space Visual Analysis Results}

\subsubsection{Represents the Author's Analysis}

Using Cite Space visual analysis software, respectively with keywords, authors, etc. for analysis, selecting CNKI-included literature as a data and manually culling irrelevant and non-academic papers, we finally obtain a valid sum of 699 articles, in the format of Refworks output, imported into Cite Space for visualization.

Select author as the analysis unit in Cite Space and run to get the map (see Figure 3). In the figure above mainly through the author's node size reflects the frequency, node peripheral annual wheel reflects the centrality of the intermediary, as can be seen from the figure, Chen Yanhong, Luqin, Shen Yang, Lei Wei, 


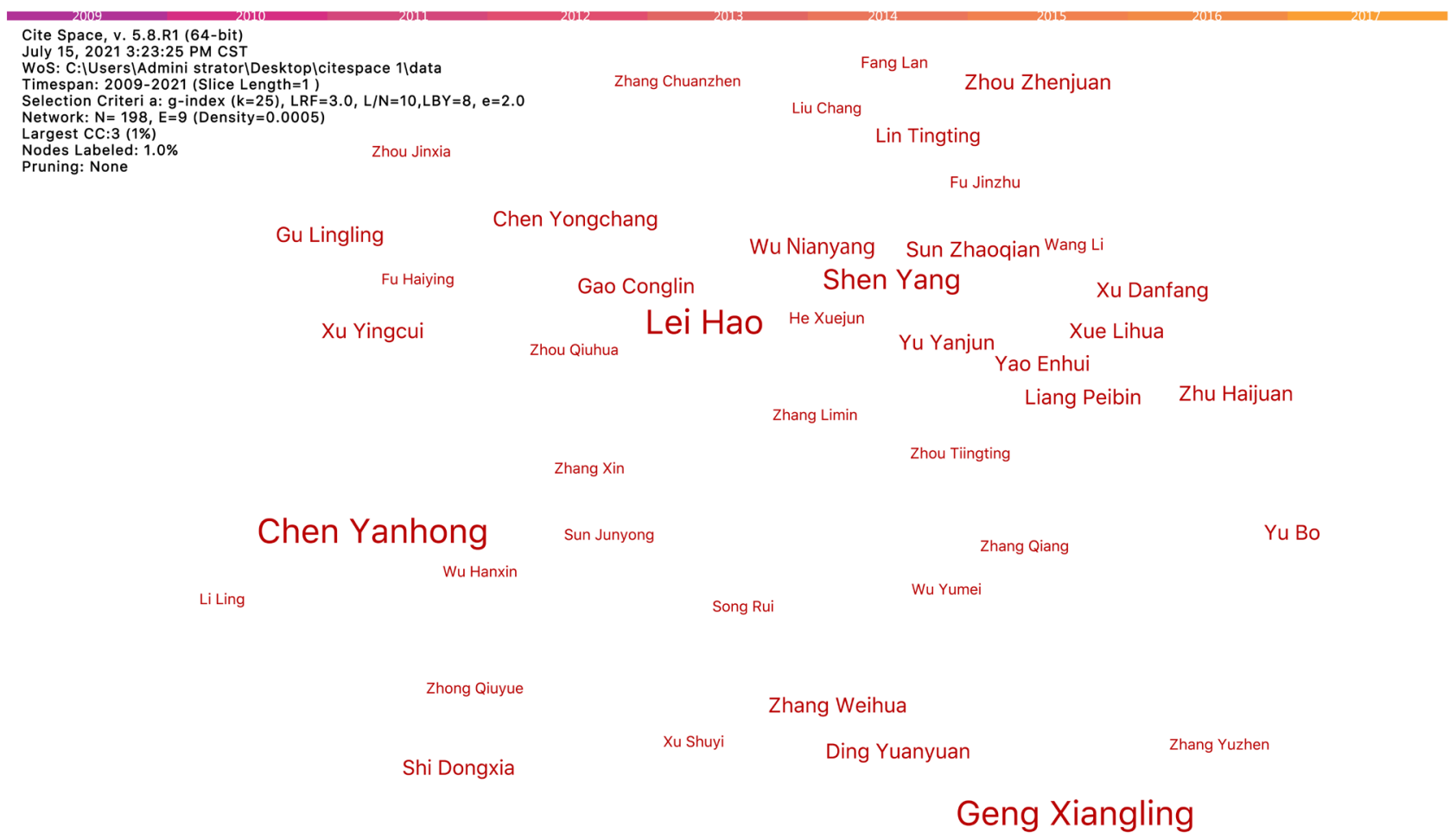

Figure 3. Author's knowledge map.

Zhou Zhengxuan, etc. are in the center of the map and form an author's network with a number of authors, which in the mathematical drawing of this research has a certain influence.

\subsubsection{Keywords Are Analyzed Together}

From the results of the keyword co-existing (see Figure 4) we can see that mathematics drawing is very extensive, but the most concentrated part of it is related to primary schools and kindergarten mathematics teaching, of which the primary school low-level mathematics drawing book teaching research is the focus in the study.

\section{3. "Mathematics Drawing Book" in the Lower Grades of Primary School Teaching in the Application of the Status Quo Combing}

If the application of "mathematical drawing book" were a big tree, then the application of "low-level math drawing book of primary school" would be the thickest main branch. After careful study by the author, it was found that the researchers mainly focus on the following three aspects: why use the "mathematical drawing book" teaching, what do you teach with "mathematical drawing" and how to teach with "mathematics drawing book".

\subsection{Why Is Teaching in "Mathematical Drawings"?}

First of all, from the characteristics of mathematics discipline, mathematics has a 


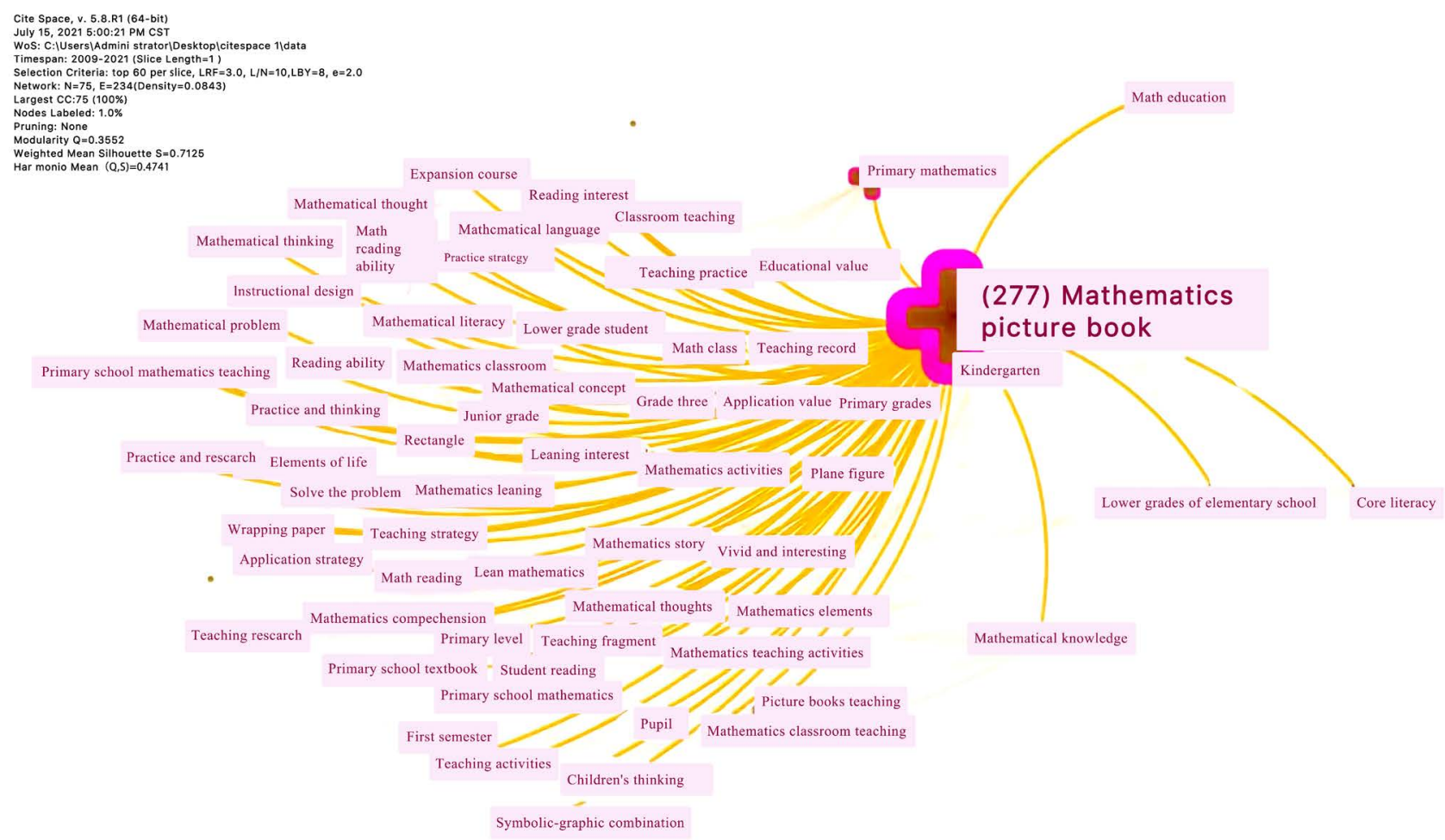

Figure 4. Keywords in the map. 
book" is that it has the taste of mathematics, in the process of telling the story, allowing students to go through the process of discovering problems, analyzing problems, solving problems, and cultivating students' ability to observe, generalize through spatial imagination and other mathematical abilities. Last but not least, "mathematical drawing" is useful. The stories in the mathematical drawing book are all based on what happens in real life as the carrier of the story. This is related to the mathematics requirements under the new curriculum, which is that mathematics teaching cannot be separated from life, leading to a life-based combination. The story in the drawing book is finished, and the mathematical knowledge contained therein is not quite finished (Zhang 2018).

It can be seen that mathematical drawing can help students better understand abstract mathematical concepts and develop the ability of information screening and combing, text interpretation, mathematical modeling and so on. In addition, mathematical reading can protect and exert students' imagination, return mathematics learning to life itself, and open up the connection between mathematics and life. "Mathematics drawing book" is to trigger the students' inner needs of a "key", driving students unknowingly to explore the colorful world of mathematics, so that students will really like mathematics (Zhang, 2019).

\subsection{What Do You Teach with "Mathematical Drawing Books"?}

Mathematics drawing is a knowledge "collection", including Chinese, science, art and other subjects of content, so what exactly is taught? At present, there are two kinds of bias in teaching for the use of drawing books: one is biased towards "drawing book". The emphasis is on "reading". The mathematical drawing book is only used as a story book, causing the lack of "mathematical taste"; In fact, first- and second-year students are curious and passionate about storylines. According to such learning laws and cognitive characteristics, the mathematical drawings are adapted and combed to extract the core problems and key knowledge points. In mathematics drawing, we should not only pay attention to text and images and stimulate students to think actively, but also to explore and interpret the "hidden line" of mathematical drawing book- "mathematical knowledge" (Wan, 2019). Therefore, the key to the teaching of mathematics drawing book is to let students find problems in the context of the story, and around it to explore and think, so that students experience and experience, so that "learning" really happens (Wang, 2019). In recent years, China's education publishing houses introduced a large number of foreign excellent mathematics drawing books. The author combed the relevant research, organized a number of teaching materials by curriculum standards corresponding to the content of threedimensional objectives of the drawing, such as South Korean titles "Love Mathematics from Childhood", "Fun Math Painting", "Hello, Mathematics" (As in Table 1).

\subsection{How to Teach with Mathematical Picture Books}

As can be seen from the table above, most of the mathematical drawings are 
Table 1. Mathematical drawing book item finishing (combined with the Western Division edition of the textbook).

\begin{tabular}{|c|c|c|}
\hline \multicolumn{3}{|c|}{ First grade } \\
\hline Unit & Knowledge point & Maths drawing book items \\
\hline $\begin{array}{l}1-5 \text { awareness and } \\
\text { addition and subtraction }\end{array}$ & Number of understandings & Tintin's Exercise Book \\
\hline $\begin{array}{l}\text { The understanding } \\
\text { of the number of less than } 10\end{array}$ & Number of understandings & $\begin{array}{l}\text { "Zero Is Not Just Not" } \\
\text { "My 123" "Kaka and His Cow" "The Cable Car That's Been Rising" } \\
\text { "Mathematics Encountered in the Gallery" } \\
\text { "Auntie Laughing Star Bread" }\end{array}$ \\
\hline Count one & Number of understandings & "First There's an Apple." \\
\hline Divide and fit & The division of the number & "Dreams of Drums and Eggs" "Strange Day" \\
\hline Than one & Compare & $\begin{array}{l}\text { "Duling Village } 168 " \\
\text { "Bibi, look. Who is big? } \\
\text { Who's small?" } \\
\text { "Length, Height and Width" "Light Words" "Don't Eat You!" "Baby } \\
\text { Bear Family" } \\
\text { "Who's Going to Eat First?" }\end{array}$ \\
\hline One point & Classify & $\begin{array}{l}\text { "Grandma's Button Box" } \\
\text { "Cubs and Noisy Monsters" "Classified SickNess Together" "Little } \\
\text { Ghost Gabe" }\end{array}$ \\
\hline Recognize graphics & Stereoscopic graphics & $\begin{array}{l}\text { "Who's the Melon Thief" } \\
\text { "Cat Castle" } \\
\text { "Cleaning Robot Grunt" }\end{array}$ \\
\hline & & $\begin{array}{l}\text { "This Is not Going to Work" "Yangyang Number of Eggs" } \\
\text { "Grandma's Red Dress" } \\
\text { "All Come to Me" }\end{array}$ \\
\hline Addition and subtraction within 10 & Addition and subtraction & $\begin{array}{l}\text { "There is Something to Get Rid of" } \\
\text { "Little Kate's Big Collection" "Lights out Time!" } \\
\text { "Escape from the Desert" } \\
\text { "Laughing Auntie's Star Bread" }\end{array}$ \\
\hline & & $\begin{array}{l}\text { "The Happier You Are" } \\
\text { "The Freckles Girl Bibi" }\end{array}$ \\
\hline 11-20 awareness of each number & Recognition & $\begin{array}{l}\text { "How Did People Count in the Past?" } \\
\text { "The Figures of the Ancient Romans" } \\
\text { "The Smallest Wind Goblin" }\end{array}$ \\
\hline The inlet addition within 20 & Addition & $\begin{array}{l}\text { "Wang Wang's Birthday Party" "Yangyang Number of Eggs" } \\
\text { "Participation in the Fair" }\end{array}$ \\
\hline Abdication subtraction within 20 & Subtraction & $\begin{array}{l}\text { "Time to Turn off the Lights" } \\
\text { "Food Chase" }\end{array}$ \\
\hline \multicolumn{3}{|c|}{ The first grade book } \\
\hline $\begin{array}{l}\text { An understanding of the } \\
\text { number of less than } 100\end{array}$ & Number of understandings & $\begin{array}{l}\text { "The World's Most Handsome Pig" "The Smallest Wind Goblin" } \\
\text { "The Worn Truck" }\end{array}$ \\
\hline Recognize graphics & Flat graphics & $\begin{array}{l}\text { "Finding the Vanishing Dad" } \\
\text { "The Adventures of the Magic Three Brothers" } \\
\text { "The Monster King of The Graphic Star" } \\
\text { "Fantastic Triangles" "Rock Math Day" "Special House" }\end{array}$ \\
\hline 100 additions and subtractions & Addition and subtraction & $\begin{array}{l}\text { "The Leaf Car" "Rainbow Marshmallows" "Sweet Candy House" } \\
\text { "Little Alien Brush Lara" } \\
\text { "Gingerbread House" } \\
\text { "The Dark Bank of Thieves" }\end{array}$ \\
\hline
\end{tabular}




\section{Continued}

Location

Yuan, corner, and division

Observe the object

In-table multiplication

$\mathrm{cm}$ and meters

Division within the table

A preliminary

understanding of the angle

Awareness of the number of people within ten thousand

Preliminary understanding of parallelograms

Three-digit addition and subtraction

Divided into meters and millimeters

Hours, minutes, and seconds

Collect and organize
Direction

Get to know RMB

Second grade

Space

"A Happy Day with Hammer and Egg"

"My Little Ninety-nine"

Multiplication

The Troubles of Mathematician Atong" "Captain of Multiplication in the Buying and Selling Country"

"Let's Do multiplication Table"

Length

"The Crown of the Big Head"

"How Long Is the King's New Clothes" “The Best Vegetables"

"Oli And His Lazy Brother"

Division

"Guess, Except for One"

"Everybody Has a Share"

Know the corner

“Two Rays Hand in Hand"

"Geometry of Origami"

Second grade book

Bit value system

"Cosmic Boy"

“Kimo’s Journey”

Parallelogram

"Who is the Prince of the Quadred Kingdom?"

Addition and subtraction

“Guess How Many".

Length

"My Beautiful Ruler"

"Three Sisters of the Bread Princess"

"My Day"

"Becoming a Good Dad"

“The Monster Kingdom's Problem"

"The Story of Time" "Ticking”

"Shentong Tribe Popularity Survey" "Spider and Candy Shop"

"Ace Car"

"Crayon Color Match"

"Annoying Chickenpox"

compiled abroad, and their knowledge framework system, knowledge generation process and China's local situation are quite different. While teaching with mathematical drawing books, it is necessary to effectively integrate and create the drawing books and teaching materials. In this process, we must pay attention to the match between the content of the drawing book and the knowledge of mathematics, the fit between the content of the drawing book and the activities of mathematics, and the thinking of the content and mathematical problems.

On the other hand, at different times, clever use of "mathematical drawing book", mathematical reading, comprehensive practice, infiltration of mathematical thinking methods, etc., will achieve the effect of doing more with less. Because the drawing book is vivid, intuitive and interesting, it just builds a bridge 
between the students' concrete image thinking and abstract logical thinking. Most researchers find that according to the unit knowledge point arrangement of the corresponding drawing book content, the application of mathematical drawing book is also very important. Some drawing books should be arranged to read before the new teaching class, so as to stimulate students' desire to explore new knowledge, and some mathematical drawing books, after cutting, adapting and reorganization can be applied to the class, thus playing a series of knowledge, and guide students according to the storyline development, step by step to explore relevant mathematical knowledge. Some are arranged after teaching to be read as an extension of knowledge (Qi, 2017; Lin, 2017). In addition, teachers can also carry out mathematics drawing book reading activities in the class. There are individual reading, parent-child reading, group reading, class reading and other forms, and some schools will regularly update the math drawing book list every year. The use of drawing book in the students; learning process, help them in the study of mathematics knowledge behind the mathematical methods, mathematics thought, mathematics spirit, so that mathematics drawing book stands in the true sense of service to mathematics teaching (Chen \& Zhou, 2019; Zhou, 2019).

Throughout the history of the application and teaching of the "Mathematics Drawing Book", it has been in the early development since 2010 and is now in hot demand. In the "mathematics drawing book" research wave, not only are there first-line teachers, but also teaching and research personnel and university scholars, etc. In general, although the current research is very hot, it's still in the development stage, and research and practice need to be further deepened, some problems need to be further improved.

\section{The "Mathematical Drawing Book" Application of the Proposal}

For the mathematical drawing book, only choose the right one and use it well. It will not live up to the drawing book itself, neither will live up to the students.

\subsection{From the Math Drawing Class to the Math Drawing Course}

In the process of combing the literature, the author found that the existing research is either a partial analysis of the mathematical drawing book, or a summary of a wonderful mathematical drawing course, but there is no systematic math drawing in this course. One or two interesting and wonderful math painting lessons, cannot fully play the role of mathematics drawin nor better serve the students' mathematics learning. In the course of practice, we must establish a structured and systematic mathematics drawing course. This requires teachers to think about the goal orientation of the curriculum, tap the resources of the mathematics drawing course, carry out the management of the mathematics drawing course, evaluate the students' learning situation, etc. (Lv, 2019). Such a math 
painting course can have a lasting impact on students, who will dive into longterm immersion in the painting culture and better understand that the mathematics painting book contains the "essence".

\subsection{From School Teaching to Family Educations}

Now that most of the research of "mathematics drawing book" is carried out from the perspective of school mathematics teaching, the research object is mostly how to impart "mathematics drawing book" class, but the dimension is relatively single, ignoring the core literacy of students as the main body of the development system research. The impact of the math drawing book on the promotion of the core mathematics literacy of students in the lower stages of primary school is not mentioned on how parents can effectively guide their children to read the "mathematics drawing book" and the "family school co-education mode". If the "mathematics drawing book" is a recommended math reading, let children read with their parents at home, according to the content of the drawing book and the production of effective parents math drawing guidebook, to help parents at home while they themselves can also effectively learn mathematics, and not only expand the limited time and space in school, but also enhance parent-child relationship (Chen, 2019).

\subsection{From Passive Learning to Active Learning}

At present, "mathematics drawing book" mostly serves mathematics teaching. Teachers and parents use mathematics drawing book as a carrier. The mathematical knowledge, methods, ideas among other things are perfectly integrated together. The purpose is to develop students' mathematical thinking ability, improve students' ability to learn independently and become a free man who can adapt to the future life. School education is to a large extent, also children follow the teacher's design and arrangements for passive completion. If students enjoy math drawing books and have the ability to read independently, they can take the initiative to find problems in the math drawing story, follow the development of the story to try to analyze the problem, from a large number of graphic information screening effective information and solving problem, hence unknowingly exercise their abilities and develop the habit of active learning. Mathematics drawing book reading allows students to increase the breadth, thickness and depth of learning, and finally let students change their way, acquire a different vision, a different kind of thinking to meet the rich, beautiful side of mathematics (Guo, 2019).

\section{Conclusion}

By using the visualization analysis method of knowledge map, this paper combs the literature on "mathematical picture books" from 2008 to 2021, and finds that the number of literature on "mathematical picture books" has increased year by year since 2012. Chen Yanhong, Qiu Luqin, Wu Nianyang and other scholars 
have great influence, and the most concentrated research is the application of "mathematical picture books" in "low primary school teaching". The research content mainly has three aspects: first, the reason of using "mathematical picture books" for teaching is mainly that the mathematical knowledge itself is boring, the children in low primary school are young, the understanding of mathematical concepts is limited, and the mathematical picture books are intuitive and interesting, which can effectively help students better understand abstract mathematical concepts and develop the ability of screening and combing information, text interpretation and mathematical modeling. Second, the teaching content of "mathematical picture books" is mainly to let students find problems in the context of the story, and explore and think around it, in which way students can experience and feel it, so that "learning" really occurs. On this basis, the author also combs and lists the picture books corresponding to the three-dimensional target content of textbooks and curriculum standards. Third, the teaching method of "mathematical picture books" is used to skillfully use the "mathematical picture books" to introduce excitement into the classroom, and carry out mathematical reading, comprehensive practice, parent-child reading, group reading, class reading and other ways to lengthen students' learning process, so that students can profoundly understand the mathematical method thought and spirit behind mathematical knowledge, and make mathematical picture books serve mathematics teaching.

At present, there are not only front-line teachers, but also teaching and research personnel and university scholars paying attention to "mathematical picture books", but it needs to be further deepened in the practice of primary school mathematics teaching, and the scope and method of its use need to be improved. Therefore, the author suggests that in low-level mathematics teaching, primary school mathematics picture books should move from mathematics picture books to mathematics picture books, from school teaching to family education, from teacher teaching to students' autonomous reading, namely from passive learning to active learning. In this way, neither the picture book itself nor the students can be ignored.

\section{Conflicts of Interest}

The author declares no conflicts of interest regarding the publication of this paper.

\section{References}

Chen, J. and Zhou, J. (2019). Exploration and Practice of Primary School Mathematics Picture Book Teaching. Journal of Hunan First Normal University, 10, 45-46. https://kns.cnki.net/kcms/detail/detail.aspx?dbcode=CJFD\&dbname=CJFDLAST2020 \&filename=DYHN201905004\&v=RPdtAHVPbHmJ4D2ylYKZXr9HK1d9BkP35IqgO6x FOgcwaZjxWUDC5Fl\%25mmd2B7KQVLg9B

Chen, Y. C. (2019). Let the Integration of Picture Books and Mathematics Teaching More Scientific-Three Problems That Should Be Paid Attention to in the Use of Mathemat- 
ical Picture Books. Liaoning Education, 4, 89-90.

https://kns.cnki.net/kcms/detail/detail.aspx?dbcode=CJFD\&dbname=CJFDLASN2019 \&filename=LNJY201907028\&vo26FmECxkV7Jq\%25mmd2F8JFnRFV0eHJLmEsZZjk MjIkS5JsYWbSfBRO2g0VH\%25mmd2B51EbCah\%25mmd2F

Guo, X. R. (2019). The 'Triple Transformation' of the Supply-Side Reform of Primary School Mathematics Picture Book Reading. Friends of Mathematics, 20, 29-32. https://kns.cnki.net/kcms/detail/detail.aspx?dbcode=CJFD\&dbname=CJFDLASN2019 \&filename=SUZY201905028\&vL3QqRzKALX9vtKA9XXIVWdVrj4dKaKwKWm0Edx HGKEhUIqGgEXpu8V9vlgwiKUjo

Lin, Y. T. (2017). Practical Exploration of Mathematics Picture Book Teaching in Lower Grades of Primary School. Chinese Teachers (Beijing), 10, 72-75.

https://kns.cnki.net/kcms/detail/detail.aspx?dbcode=CJFD\&dbname=CJFDLASN2019 \&filename $=$ ZGJT201719021\&v=KnzNSKnIIdxP0SzNWYvkLlsj9W7lVgYjXlhgeSZwR1 VcjuISaBTWKqYUmVTT2kZ8

Lv, X. X. (2019). Present Situation and Suggestions on the Use of Picture Books In Primary School. Jiangsu Education, 8, 8-11.

https://kns.cnki.net/kcms/detail/detail.aspx?dbcode=CJFD\&dbname=CJFDLASN2019

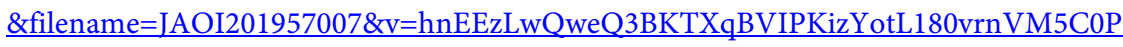
wQxF7VU57DhMgApAzkRUMhGg

Matsui, T. (2017). My Picture Book Theory. W. X. Guo, \& X. J. Xu, Trans. Xinjiang Youth Publishing House.

Qi, S. Y. (2017).Talking about the Small Strategy of Integrating Mathematical Picture Books into Classroom Teaching-Taking the Teaching of 'Preliminary Understanding of Angle' as an Example. Mathematics Teaching Communication (Chongqing), 10, 3-5. https://kns.cnki.net/kcms/detail/detail.aspx?dbcode=CJFD\&dbname=CJFDLASN2019 \&filename $=$ SXUJ201719003\&v $=$ ZC00k\%25mmd2BhFyGCZ4WNqFKsKqfEoehCFHNc CrLzMT9R3ktpG0jMZ5m\%25mmd2BeCn0m4zZjDXcG

Wan, Y. Y. (2019). 'Painting' Teaching Blueprint Seeking 'Mathematics' Origin-Jinxi County Jinxiu Primary School Mathematics Picture Book Teaching Practice Exploration. Jiangxi Education, 1, 30-32.

https://kns.cnki.net/kcms/detail/detail.aspx?dbcode=CJFD\&dbname=CJFDLASN2019 \&filename $=$ IWAS201902005\&v=Fb1XjENUIXw7yIynuXBORgCfpa0nCD6WXZUp4A 8700D4j3tH5DnaAVp1FhrDYJq

Wang, L. P. (2019). Using Mathematical Picture Books Let Primary School Mathematics Learning Really Happen. Mathematics Learning and Research, 13, 16-18. https://kns.cnki.net/kcms/detail/detail.aspx?dbcode=CJFD\&dbname=CJFDLASN2019 $\underline{\text { \&filename }=\text { SXYG201913145\&vrLUCXcTYvKyDUqB5EcKO\%25mmd2BJhccWS24i3Rf }}$ kxWv\%25mmd2Bn7jKUflVFfDpQdAnEZTFuzdtf

Zhang, F. (2018). Mathematics Picture Book Teaching Let Rational Mathematics Encounter Perceptual Pictures. Mathematics Teaching Newsletter, 10, 14-15.

https://kns.cnki.net/kcms/detail/detail.aspx?dbcode=CJFD\&dbname=CJFDLASN2019 \&filename=SXU/201828003\&v=rYRYpMpgysbliTiewi3ueIdjRTaeI57dVqVWt1xdJY6L 59PILNO2J8b5gzUUutu

Zhang, X. (2019). Enter Mathematics Picture Book Reading. Master Online, 4, 25-28. https://kns.cnki.net/kcms/detail/detail.aspx?dbcode=CJFD\&dbname=CJFDLASN2019 \&filename $=$ MSZX201904044\&v $=$ wSEo4cd96Px4I48Okmp0Tox8OkGnCeukRWjXzTR 554CElIOipL14Zk7hWLfBLZht

Zhou, Z. J. (2019). Children's Eyes Look at the World, Children's Painting Mathematics-Children's Mathematics Painting Diary Creation Practice and Thinking. Jiangxi 
Education, 10, 30-34.

https://kns.cnki.net/kcms/detail/detail.aspx?dbcode=CJFD\&dbname=CJFDLASN2019 \&filename $=$ IWAS201929017\&v=Fb1XjENUIXwSh3qRoEY3fIKxMDll7vRNV18k6ZEu SU9tesuslvc2vOD9qIR9w2x0 